\title{
Secondary Education under Tension between Democratization and Modernization: Reflections from the Brazilian Experience
}

\author{
Eliza Bartolozzi Ferreira ${ }^{1}$ \\ ${ }^{1}$ PHD Professor of the post graduate Program in Education of the Federal University of Espirito Santo State, \\ Brazil \\ Correspondence: Rua João Nunes Coelho, 50/101-Vitória City/Espírito Santo, Brazil. Tel: 55-279-8866-9697. \\ E-mail: eliza.bartolozzi@gmail.com
}

Received: February 26, 2016

Accepted: March 31, $2016 \quad$ Online Published: August 25, 2016

doi:10.5539/ies.v9n9p157

URL: http://dx.doi.org/10.5539/ies.v9n9p157

\begin{abstract}
This paper analyzes the extension of the right to secondary education in Brazil. Currently, the debate on secondary education has been intensified in civil society highlighting the problem of the reason of its precarious offer, not to mention a significant proportion of young people and adults who have not finished this level of schooling. Opinions vary on how the offer to secondary education should be held: while a minority believes that schooling should be humanistic and scientific; others support integrated education with a technical certification. Others advocate the separation of secondary professional education. This myriad of projects and programs has invaded the educational systems and schools, a portrait of public action in the education area, divided between republicans and private interests, in the context of disputes between the process of democratization and modernization, guided by the excellence of the performance of the institutions and students. This paper has an essay character produced within the research 'Innovative High School Program: working conditions and teacher education' with CNPq funding and during the post-doctoral studies conducted at the École Normale Supèrieure de Lyon/France, with CAPES financial support.
\end{abstract}

Keywords: democratization, modernization, right to education, secondary education

\section{Introduction}

Half a century ago, a profound expansion of schooling (and its consequent massification) was processed in the capitalist countries, a process characterized by some scholars as an 'education revolution' (Esteve, 2006). This expansion occurred from the development of an ideology based on the importance of education in an increasingly competitive world. The main result of these transformations would be a new institutional period, which emphasized individualization of educational trajectories. In this sense, the problem of social cohesion and the discussion of the role of schools in the development of citizenship were placed.

Nowadays, we observe the strengthening of a pragmatic perspective around the debate on the role of school between educating and instructing with the assumption of the discourse of efficiency and the development of cognitive skills. The massification and the lengthening of schooling bring the problematic role of the State in education towards an adjustment in the context of fiscal crisis. The allocation of financial resources and the implementation of international assessment systems become priorities for education policies. With this, the education institution and the organization of educational work undergo significant changes with the advent and diversification of political and social action.

Nevertheless, to present low enrolment rates compared with developed countries, Brazil shares this 'education revolution' with increasing levels of inclusion in preparatory school and higher education. This process of democratization of the best social policies observed after the 1990s was challenged by the demands of modernization based on the criteria of efficiency, effectiveness and quality of the neo-Taylorism rational (Lima, 2003).

The end of Brazil's military dictatorship (1964-1985), the result of a democratic transition negotiated between politicians and businessmen pressed by a severe economic crisis expressed by a high rate of inflation and foreign debt, besides the reduction of the purchasing power of the population and the strong presence of social movements, marked the revival of the country towards the modernization of its political and economic structures 
and the democratization based on the capitalist globalization. In this scenario, education has been a fertile area of experiences tensioned between the agenda of modernization and democratization. Roughly speaking, the modernization of education means to follow the principles of economic rationalization, based on efficiency, effectiveness and performance at a lower cost-democratization of education understood not only as a massification that retains the intellectual and social inequalities, but also as an achievement of the right to education and the participation of social groups in the education debate.

Therefore, while the democratization of education takes place as a social and historical demand, its management should be made by measurable performance results and constant flow of enrolments and dropouts. The expansion of schooling for the poorest sectors of the population began in the 1990s and was developed through a practice of decentralized management to local authorities, public and private organizations, which are now encouraged to adopt instrumentalist character procedures for achieving good results measured by national assessments. Generally, there is a mismatch in these procedures because most educational institutions needed a pedagogical project that enhanced citizenship and encouraged a collective and integrated work organization of various and numerous tasks performed by teachers. However, the opposite occurred, the democratization of education presented an excluding profile and may be called 'excluding inclusion' in Kuenzer's (2007) (Note 1) words, as it includes more individuals in school to later exclude them in the form of evasion or by offering a standardized education with no quality. In other words, the expansion of schooling for Brazilian people exposes more forcefully the drama of the schools' failure and reveals the establishment of poor schools for the poor.

Since the 1990s, neoliberal policies have emphasized mass expansion of education with the increasingly strong presence of the technocratic rationality that materialized by efficiency and effectiveness goals registered through instruments applied on a large scale. The defense is for the school to recover its delay, incorporating the criteria of productivity and quality similar to economic organizations. Strictly speaking, it is in this context that the right to education is grounded in Brazil.

The coexistence of these political and economical forces presented themselves more ambiguously in the democratic administration of President Lula da Silva (2003-2011) (Note 2). Thus, this paper aims to highlight the ambiguity seen in the formulation of education policies for the education of young people 15 years old or more (secondary education level). The central argument is that the heterogeneity observed in the offers of secondary education models reveals the coexistence of oriented forces dictated by diverse interests - on the one hand by international organizations, but on the other hand by social actors that enter the scene in the democratic context of the right to education.

Education in Brazil is a duty of both the State and the family, so its offer is public and private. The reality is of an institutional universe divided as a result of social processes which engenders a strong individualization of educational pathways. Public and private sectors of the country offer 'regular' secondary education with a curriculum focused on 'vestibular' (Note 3) exams and/or the National High School Exam (Enem). Its role is to select young people to continue their studies and provide professional qualification at higher education level. It also has the role to offer secondary education integrated with vocational education by the Federal and State School systems represented by the former technical schools (whose access is through a selection process).

Another type of public offering is represented by an innovative secondary education model, which despite having the working field as an educational principle, it is not professional education. It requires greater school workload than that practiced by 'regular' secondary education, i.e., it proposes the student to stay in school longer. It is important to highlight the public offering in secondary schools for young people and adult education. They coexist with the same educational settings as other types of school offers and the adult and young adult educational programs articulated to professional education (Proeja), which aim to qualify adults and young adults who did not have their right to education exercised at the right time for the working area.

Currently, the debate about Brazilian secondary education has been intensified and much publicized in the mass media. The debate highlights the national problem of its offer and the reason why it is precarious. It also shows a significant proportion of young people and adults who failed to comply with schooling. Opinions differ on how this offer of education should be made: while a minority believe that education should be humanist and scientific and for all; others advocate the integrated secondary education with technical qualification certification; another part is for the separation of secondary and vocational education based on the Human Capital Theory.

Different opinions on secondary education are translations of the various interests that underlie the social and educational area, which is increasingly influential and a protagonist of public policies that have been guiding the market, the curriculum, the organization and school funding. Various segments of society have become aware that they cannot continue to repeat the past, but there is little consensus on what the Brazilian secondary 
education should be. In general, the population is convinced that the school should prepare young people for the labour market that appears increasingly competitive. So there is the strengthening of a culture eager for results.

The right to education, still being established in Brazil, starts to coexist with the guidelines for the right to learn from a more individual-centered perspective and the value of practical skills necessary for social coexistence and work. The most aggravating factor is that education policies follow a privatized orientation in a country with deep inequalities of national wealth ownership.

The hypothesis discussed in this paper is that the heterogeneous offer of secondary school is a result of structural and cyclical ambiguities that pervade debates about the efficiency and the right to education. In other words, its form of organization is directly related to the strain between the process of democratization of society and the global modernization project.

This paper has an essay character developed from documental and bibliographic studies and analysis of statistical data produced by official agencies (IBGE, INEP, IPEA), which reveal the problems of secondary education in Brazil. The studies were conducted within the research 'Innovative High School Program: working conditions and teacher education' with CNPq funding and during the post-doctoral studies conducted at the École Normale Supèrieure de Lyon/France, with CAPES financial support. This set of study experiences and investigations shows the presence of disputes between social actors who move among educational projects aimed at democratization and modernization of the Brazilian education system.

The theoretical and methodological approach adopted seeks to approximate the cognitive analysis of public policies that seeks to respond to a double ambition: to integrate the dimension of the global that seems to be fundamental to understand the logic of work on changes in public policies, highlighting the role of actors in the construction of world conception and the concrete implementation of the global and 'sectoral' dialectic (Muller \& Surel, 2002). Given the context of public policies in contemporary times, the multiplicity of cognitive dynamics is an important variable because they express different 'worldviews', often conflicting, highlighted here by modernization and democratization as used in policy formulations for secondary education. It is important to emphasize that regardless of Secondary Education being predominantly the responsibility of federal state entities, the period studied here was fertile in the planning and implementation of national policies that seek to undermine the state. The performance of the policies at each level will depend on complex variables where several objective and subjective elements will interfere and particularize the course of the educational process. Despite the fact that this text does not address these characteristics, we consider that these political processes constitute relevant objects for research in education policies.

This text is organized into four sections, besides this introduction and closing remarks. The first section gives the reader an overview of the Brazilian historical context and the organization of its education. The second section provides a discussion of education policy in order to discuss in the third section the constitution of the right to education. In the fourth section, we point out some contradictions of the offered policies for secondary education in Brazil that reveal the coexistence of different projects that do not form a synthesis, but reveal the trajectory of a country that later places the right to education and integrates it to the logic of pursuit for excellence of results.

\section{The Context: A Brief Critical Outline of Brazil and Its Education (Note 4)}

The Republic in Brazil was established in 1889. This provoked an economic boom that made the country the world's eighth largest economy, but without performing the classical reforms of contemporary capitalism, such as taxation, agrarian and social. Throughout the period of the Republic, it is the first time that democracy reaches 25 years (1990-2015) of continuous existence with the presence of free elections for all those who govern the country: President, Governors for 26 regional states and a Federal district, and Mayors for 5,570 cities. This short democratic experience reveals the absence of a consolidated democracy, which leads us to understand that this is one of the reasons for the permanence of conservative forces in power and the presence of extreme social inequality in the country.

The concentration of income and wealth is a mark of Brazil. For a country of continental dimensions with an area of 8.5 million square kilometers and a population of 201.5 million inhabitants (IBGE, 2013) (Note 5), distributed between urban (85\%) and rural $(15 \%)$ areas, Brazil has an extremely uneven pattern of development with $90 \%$ of the population owning only $25 \%$ of the national wealth $-75 \%$ of the wealth accounted for in the country is absorbed by the richest $10 \%$ part of the society (Pochmann, 2015).

After the long period in which it remained a colony of Portugal, and later an Empire (1500-1889), Brazil joins the world capitalism from a concentrator and exclusionary standard of development, with a strong presence of a patrimonial elite that remains and reproduces itself in power, making use of public wealth and space in favor of 
private interests. Inequality can be observed not only between regions of the country (e.g., the Southeast - São Paulo, Rio de Janeiro, Minas Gerais and Espirito Santo concentrate more wealth than the nine states of the Northeast region), but also between different social groups, especially among those of black and mixed-race color corresponding to 106 million Brazilians (PNAD, 2013). The uneven condition that affects black people in Brazil relates to them being the main victims of violence and those who suffer most from poverty. In 2011, IBGE reported that the rate of black youth homicide in 2010 was $72 \%$. While the rate of white youth homicide in Brazil between 2002 and 2010 decreased from $40.6 \%$ to $28.3 \%$, the rate for black youth, which was already high, increased from $69.6 \%$ to $72.0 \%$.

For nearly one hundred years, education remained a prisoner of the conditions of production and reproduction of the Brazilian underdevelopment. Indeed, from the establishment of the Republic in 1889 to the Federal Constitution in 1988, the advancement of public education was not continuous, marked by the burden of slavery and the traces of a patrimonial society. Until the 1940s, the inclusion possibilities of black children in public schools went from nearly zero to none, hence the significant portion of the country's illiterate in the early 21 st Century being over 55 years old and not white. At the same time, the appropriation of the patrimonial state by strict social groups transformed the good public school in an almost exclusive reproduction of a white elite, without giving possibilities for universal access to the entire population (Ferreira \& Pochmann, 2011).

Nowadays, the Brazilian education system is legally organized in two levels: basic and higher education. Basic education is divided into three stages: Early Childhood Education, which formally comprises the age group 0-5 years old; Elementary School, 6-14 years of age and Secondary Education, 15-17 years old. It is a decentralized system, in which the pre-school and Elementary School are of the responsibility of the municipalities, while Secondary Education is primarily the responsibility of the States and the Federal District. It is the responsibility of the Federal Government, among other duties, to act in Higher Education and provide technical and financial assistance to the State and municipalities, seeking to ensure fairness of the expenses to the different units of the federation.

The purpose of basic education is to develop the students, assure them the indispensable common education for citizenship and provide them with ways to progress at work and in their later studies. In addition to the three stages, basic education must ensure the integration of all types of education (Adults and Young Adults, Professional Education, Special Education, Rural Education, Indigenous Education) and ensure individual trajectory in its specificities.

After 2009, the right to Basic Public Education extended to the entire population for 4-17 year olds. Enrolment in Basic Education still does not reach the entire population though. Only $81.2 \%$ of children aged between 4 and 5 years old are in school. The population aged between 6-14, 98.4\% are enrolled, and secondary education, teenagers aged between $15-17$ years old, $84.3 \%$ are in school. Contrary to what occurs in higher education, the majority of the enrolment in basic education is in the public sector. Children and youngsters between zero to 24 years old constitute $31 \%$ of the total population. Data shows that it is a country that has suffered the aging phenomenon of the population and a falling birth rate.

Quantitative democratization is a slow process when the data from the National Household Sample Survey (PNAD/IBGE) is analyzed concerning the number of years of the schooling of the population at the age of 10 or older. In 1993, this population had an average of 5.0 years of study; ten years later, in 2003, there was an increase to 6.4 years and, in 2013, the population reached 7.6 years of study. The compulsory basic schooling time for all Brazilians (Constitutional Amendment No. 59/2009) is 13 years. This modest growth in 20 years of access policy implementation and permanence reveals the instability of educational policies implemented over the years. Therefore, it is a permanent challenge to overcome the historical problems of Brazilian education, not to mention the weakness of the qualitative aspects denounced by large-scale assessments, even though they are mechanisms that reflect quality with reference to social well-being for the majority of the population.

Even though there are significant numbers that reveal the amount of challenges in Brazilian education, these numbers show progressive improvements. For example, the illiteracy rate of people at the age of 15 or older is estimated at $8.5 \%$ (it corresponds to 13.3 million people), with a big proportion concentrated in the population aged between 40 and 59, and even higher among people over 60 years old. In 1997, the rate was 14.7\%.

In higher education, the attendance is still very low in relation to the population of the age group 18-24. According to the Census of Higher Education (INEP, 2013), total enrolment in higher education is 7,526,681, with $74 \%$ concentrated in undergraduate institutions. The percentage of people attending higher education represents almost $30 \%$ of the population aged between $18-24$ and around $15 \%$ are in the age theoretically recognized as ideal to study at this level of education. It is important to notice the progress made in recent years 
the rise of young people aged between 18-24 with access of up to 1.5 times the minimum wage attending higher education: this number increased from $11.9 \%$ to $40.8 \%$ of the total. Therefore, the data leaves no doubt that there has been increased access for this low-income segment to this level of education. This is closely associated with affirmative actions implemented during the first decade of the year 2000.

In the late $20^{\text {th }}$ century, a set of political and economic reforms initiated an increasing diversification of roles played by the State in relation to education. While the State led (and controlled) the expansion of education, it encouraged the education market in offering both basic and higher education. In fact, there was a significant expansion of the offer and enrolment in Brazilian schools that can be understood as a massification. This process has been developed without any concern about the quality of education, but as encouragement to boost the private sector.

The neoliberal project to reduce the size of the State in Brazil had emphasis during Cardoso's administration (1995-2002) despite the fact that the control remained firm, particularly through evaluation systems deployed on a large scale. This trend of expansion of the private sector of education continued during Lula's administration (2003-2011), as shown by official data of the Ministry of Education, confirming the reduction of 2.6 million enrolments in the public school system between 2007 and 2010. By contrast, the private sector gained 1.2 million and enrolments grew by $18 \%$ in the number of schools, meanwhile the public network shrank $6 \%$ from prep school to secondary education (Carta Capital, 2011).

These privatization processes bring serious social and political effects to education - they augment educational inequalities. Besides the traditional difficulty of establishing a common educational project, dominated by the private education offer to the ruling class and a plurality of cultural models, segregating education policies deepen the individualization of education pathways.

Within this framework of thought, this paper argues that the late process of democratization of Brazil and its education was questioned by the imperative logic of economic and cultural globalization (recognized as modernization), which founded certain aspects that highlighted the logic of effectiveness, efficiency, focus on achieving the right solution, optimization, priority in a favorable cost/benefit relation and progress. Certainly, this strategy seeks to bring public institutions to find new organizational paths that approach them to their counterparts of the private sector. This practice causes limitations in the development of the democratic management experience of the last 25 years of public education.

\section{Situating the Debate on Education Policies: New Actors Come into Play}

The introduction of new theoretical and methodological frameworks to address education policies is a result of the transformations elapsed in the last quarter of the $20^{\text {th }}$ Century guided by new forms of regulations in the education area. The relationship between the State and education has been accompanied by a greater concern of the State in controlling its efficiency and its measurement, as the principle of governance is to break the traditional, hierarchical and vertical forms in favor of the dialectic between the global and the local.

In Brazil, during most part of the $20^{\text {th }}$ Century, the tendency to transfer the role in education policies to the sectors responsible for planning the economic development of the country was predominant. This trend was complemented by the new practices of President Lula's administration when he merged the debate and projects with other actors, for instance, the approach established by the Ministry of Education with the universities. This was the moment that the right to education was expanded, and at the same time much of the scientific production started being 'ordered' and incorporated by the policies and governmental plans, despite achieving the necessary conditions for the implementation of a particular education policy.

In this antagonistic relation trajectory, Lula da Silva's administration undertook discussions about educational programs that aimed at a worker's schooling linked to a curriculum focused on job categories, science and culture, and also professional development. However, the financial and technical resources invested in the implementation of such programs, allied to the obligations imposed by the federal organization of the country, revealed uncertainty in the implementation and achievement of the established objectives.

In the context of democracy and the adoption of decentralized policies, civil society was invigorated after social struggles were undertaken by social movements and organizations of the 1970s and 1980s that claimed rights and space for social participation. This new civil society is recognized as a legitimate existence of a space occupied by a number of institutions located between the market and the State, playing the role of mediators between organized groups of individuals and institutions of the governmental system.

New social actors in the Brazilian society that emerged after 1970, over the heads of the State and against it at first, configured new areas of participation and social relationship formats. In the 1990s, according to Gohn's 
(2011) analysis on social movements, social conflicts simply ceased to be repressed or ignored and started being recognized, inserted and continually reinserted in the negotiation agendas. At the same time, the scenario of social struggle was redefined and shifted. In this scenario, many of the social movements came into internal militancy and credibility crisis along with the population, and many of the policies were formulated to social segments in a perspective that emphasized problem-thematic areas and not social actors organized into movements. To Gohn (2011), this indicates a shift in values and guidelines that inform and ground social action.

This context was strengthened by the demands of social actors located in educational systems and in the vicinities of schools, designing educational institutions as small enterprises able to manage their resources to meet the good learning outcomes provided by the evaluation systems created by national and subnational governments. These management strategies incorporated a vision that focuses on the rational organization of the system, stimulating the acquisition, by school officials, of managerial attributes that emphasize physical and financial management of the school. This practice, which is considered necessary to modernize education, tends to standardize teaching and reify pedagogical relations.

During Lula da Silva's democratic and popular administration (2003-2011), the local government was strengthened and consolidated and saw itself more accustomed to the participation of individuals in councils and collegiate organizations. In other words, the public and private actors began to participate in the dispute of educational projects with the aim of schools efficiently fulfilling its teaching objective.

With the participation of these individuals, strengthened by the decentralization of education policies, the instrumental rationality continued to determine public and private actions. The State, in accordance with its obligation to present results established by international bodies, assumed as a priority the evaluation of educational systems and the establishment of rates to check the quality of services. The Government adopted the logic of hierarchical control replaced with self-control, obligation to means with obligation to results, and regulations with evaluation. In this dialectic of the adoption of centralized and decentralized policies; democracy and global modernization; the State has incorporated the new social actors in the formulation and implementation of public policies. Thus, the researches in education policies began to focus on the confluence of forces and actors involved in the formulation and the implementation of education policies in the context of reforms in recent times. It means that, with the transfers of policies to the local context, governments alone do not exercise the power to make policies, but share many of its duties with other social actors. As a result, a review of the tradition of education policy studies focused on understanding the role of the state is done in order to make an approach that involves other engaged actors who, along with the State, promote public action.

Hence, the presence of new and multiple public actors caused by the decentralizing policies of the governments over the past 20 years make social reality complex and, consequently, the investigations, because it fragments and eases social action. A variety of actors mobilize knowledge to act politically and, more than once, political actors are required to justify their proposals and their options. Delvaux (2007) argues that increasingly, their own public policies put into practice regulating ways based on the diffusion of knowledge. These developments were summarized in very poor notions like 'knowledge society', 'new public management' or 'post-bureaucratic'. This idea suggests that the State no longer has a leading position in public action, as it unfolds on multiple and interdependent levels.

From the perspective of the studies on public policies, new challenges appeared as social policies of universal character providing a venue for the politics of a compensatory nature. Considering education policies within the framework of reforms developed after the 1990s, new borders were shaped between public and private that are worth being discussed, drawing on the idea of the right to education as increasingly placed as a political horizon of national citizenship.

\section{The Right to Schooling in Secondary Education and Its Limits}

Recognition of the importance of the right to education in Brazil is consolidated only in the Federal Constitution of 1988. Despite the advances made in recent decades, the social debt that the country has with its population is still very high because there are millions of children and young adults out of school or included in school but excluded from its benefits. Brazil has a complex and flexuous historical path, as it was born as a colony with strong racial and social hierarchy. Thus, equality was not the principle that guided social rights in its early years of formation in the 20th Century.

Secondary education in Brazil is the stage of basic education that presents major problems and challenges. There are several reasons that lead to this scenario of difficulties, which include: 1) it is more directly linked to market demands in the education and qualification of the work force as the last stage of basic education; 2) there is lack of consensus on how the curriculum should be, whether or not integrated with professional work ; 3) $84.2 \%$ of 
young people aged 15-17 are attending school, but only 54\% are enrolled in secondary education; 4) it shows an increased inequality because young white people at the age of 15-17 have a higher school attendance, $62.9 \%$, whereas young black and mixed race people have a $47.8 \%$ attendance; 5) $32.3 \%$ of young people aged $18-24$ did not complete secondary education and were not studying in 2012. Early school dropouts reach half of these young people who belong to the poorest fifth $(53.4 \%$ ), whereas the richest fifth proportion is $10.2 \%$ (IBGE, 2013).

The discussion on secondary education presents some points that guide this analysis, being decisive the notion that there is a difficult equation in shaping its identity because it has always been divided between offering professional education or an introductory teaching focused on the pursuit of studies at a higher level. With the enactment of the Law of Directives and Bases for National Education (LDB/1996), secondary education took the form of a stage of basic education, the third and the last one, with the responsibility to consolidate and deepen the knowledge acquired in primary school to further education; to provide a basic preparation for work and citizenship, with the development of intellectual autonomy and critical thinking, combining theory and practice. According to Cury (2011), from a legal standpoint, secondary education is neither a door to higher education nor a key to the labour market, although it is a requirement for both higher education and technical education.

Kuenzer (2010) calls our attention to the need to incorporate all forms of education design in basic education, establishing its integration and ensuring its organicity. According to the author, it is important to take ownership of the design of basic education as a whole. This means organizing education as a system that admits no parallel forms that compromise the assumed integration between the stages and types of education offered by the school and other educational activities that occur in the set of social practices. This ensures both internal and external organicity to basic education, articulating, through education mediation, knowledge, work and culture.

It was only in 2009, with the enactment of the Law No. 12061, that secondary education became compulsory, as it was in a secondary position within the education policy of the Ministry of Education (MEC), despite the participation of social groups in institutional spaces of negotiation. Even without the legal apparatus of the law, access to secondary education underwent strong growth over the period 1988-2007, with a growth rate of $219 \%$ (IPEA, 2009), a tendency mobilized by pressure of the increasing access to primary education and by the specific requirements of the work market experienced in the 1990s. However, the attendance rate in secondary education is still very low, being a little above $50 \%$. This new law poses a major challenge for the Brazilian society in the fight for basic education rights.

The analysis of the challenges of Brazilian education cannot disregard the comprehension of the relationships with international bodies such as the World Bank, Inter-American Development Bank (IDB) and the Organization for Economic Cooperation and Development (OECD), as the global agenda for Latin American countries on the grounds of giving grants for improving education policies remains. The analysis of Tello and Mainardes (2014) influence on the World Bank and IDB on policies for secondary education in Latin American countries in the post-neoliberal context point out that countries continue to seek funding for their educational policies as in the 1990s. In turn, the recommendations of these organizations seek to influence the curriculum and evaluation of education systems so that they meet the principles of competition and cooperation.

The same can be observed from the influence of the OECD in Brazilian education with the participation in the Program for International Student Assessment (PISA), whose goal is to produce indicators that contribute to the discussion about the quality of education from the comparison among countries. With the results of PISA, Brazil verifies its disability and also its effectiveness. The report 'Education at a Glance 2012' (OECD, 2012) recommends that, in the context of changes in the global economy after the recession of the years 2009 and 2010, countries must ensure a good balance between the provision of adequate public assistance in education and the requirement that students and families take over part of the costs.

These expressions of globalization in Brazilian education largely worsen social inequality, the heterogeneity of the teaching offer and the privatization of education. Above all, globalization announced the end of illusions that a school diploma would provide equal chances. In addition, it showed the State is no longer the great mastermind of education to encourage private offering, strengthening the great educational markets. This evolution of the problems observed in several countries emphasizes the management production and teaching perspective with serious consequences on the curriculum that limit what should be taught and learnt at school to international effectiveness indicators.

In 2003, the democratic and popular government mobilized various social groups in discussion forums on secondary education. The new actors who entered the scene were the social movements, trade unions and the academy that until then had limits in participating in a dictatorship context, and then neoliberal, both not very 
open to the effective presence of these actors. A process of education policies review for young people was initiated towards inclusion in the labour market, in Hobsbawm's (2005) view, it is not only the labour activity in its strictest sense but also the conditions of life of the worker, with their political and cultural connections.

\section{The Provision of Secondary Education in Brazil and Its Paradoxes}

Modernity in Brazil brings the burden of the social origin in the educational background of different social classes. Secondary education has the structural duality as an explanatory category of its constitution. Therefore, understanding secondary education goes through the discussion of professional education from its creation, in the early 20 $0^{\text {th }}$ Century, of professional schools and, later, in the 1940s, when secondary school was created. Both offers defined the intellectual and/or operational functions of every Brazilian according to the stages of development of productive forces.

The expansion of educational opportunities proceeds after the 1950s due to the pressure of popular movements of large urban and industrial centers in Brazil, making the educational structure suffer changes with the enactment of the Law of Directives and Bases of National Education (LDB No. 4024/61). For the first time, the law recognized the integration between professional and secondary education with the establishment of equity between professional and preparatory courses for further studies.

However, the structural duality remained because two distinct branches of education continued to exist. This limit was faced with the reform of the legislation in 1971, through the Law No. 5692, which established a compulsory professionalization in secondary education. Due to that, all students started to have the same learning path. The distinction was no longer among branches of education, it was among curricula related to professional qualifications. This change came to meet the expectations of strong economic growth achieved through the industrial development of the country, which demanded a skilled workforce at technical level. In 1975, with the Decision 76, then with the Law No. 7044/82, the mode of general education was re-established, with an optional character for professional education, in service of the interests of the private sector. In 1996, with the new LDB (Law of Directives and Bases of National Education), secondary education should have met the formative role, being the offer of responsibility of the states. The text of the Law No. 9394/96 stated the relationship between the formation of secondary education and work formation, which would enable an organization from that model, if the Decree No. 2208/97 had not prohibited the junction of this offer. Thus, secondary education became one and non-professional. Between 1997 and 2004, there was a significant expansion of private professional education in the country, because there were few public places offered in a setting of high demands of professional qualification and extreme unemployment rates.

After 2003, when Lula da Silva's administration began, the discussions about education and labor became stronger in order to change the orientation in education policies, as there was a dichotomy based on education, qualification and certification for work as established by the Decree No. 2208/1997. During this period, the Ministry of Education organized two large specific seminars on secondary education and professional education (May 2003), involving the academic community, public and private school systems and unions, which had as its central agenda the reconstitution of the offer of an integrated education through the public school system. The prospect was to develop an education policy that aimed to increase the education of young people and adults and to improve the quality of the education for the worker. To this end, there was a consensus of the need for the government to organize another legislation that would allow schools to offer secondary education along with professional education.

That was how the Decree No. 5154/2004 started to organize professional education in the country, and subsequently signed into law (Law No. 11741/2008). This law altered the LDB provisions to rethink, institutionalize and integrate the actions towards professional education, adults and young adult education, and the professional and technological education. The enactment of this law can be considered an advancement of educational policies and an answer to many teachers who struggle for the establishment of a State policy for the integrated offer of technical courses with emphasis on the education of workers combined with a professional qualification process.

With the new legislation, the government implemented the Integrated Education Program and the National Program for Integration of Professional Education in Basic Education in the mode of Adult Education (Proeja). Both programs have as their pedagogical principles a polytechnic education. This policy means, above all, to ensure secondary education as a basic formation, something necessary for all young adults and adults, combined with technical education.

These programs can exemplify the argument developed in this text about the democratic aspects of education policies, aiming towards the inclusion of the popular classes to a previously non-existent education for the poor. 
Proeja, for example, originated from the Ministry of Education's organization of a group of professors of public universities with a theoretical tradition based on Paulo Freire's perspective to meet the demand of millions of men and women over 18 who had not completed basic education (Oliveira, Scopel, \& Ferreira, 2013).

In defense of pedagogical aspects focused on workers' education, Proeja forced the institutions considered of excellence in the country-the Federal Technological Education Network-to enrol young people and adults who had been marginalized from the regular school process due to, in general, the denial of their rights because they were poor. Researches that were conducted (CAPES/PROEJA/SETEC, 2012) revealed that teachers and students began to live a new school experience, but so far one cannot claim to have achieved success. All the effort of creating the program and its application in the Federal Technological Education Network has been affected by various problems of managerial character. Managers of these educational institutions, as well as some teachers, showed little interest in attending this student profile, because they have low productivity and lack a knowledge base required to perform some cognitive advances. In this sense, the managers have adopted several procedures that can circumvent the law when they offer fewer vacancies as stipulated by law. Another form of boycott is made in Proeja student's daily life.

A research conducted by Oliveira, Scopel and Ferreira (2013), developed at the Federal Institute of Education of Espirito Santo (IFES), shows evidence of various forms of exclusion of Proeja students:

My view on Proeja is a very good one, I learned a lot from my teachers and classmates, but, unfortunately, Proeja is still too discriminant, even to borrow books from the library there was discrimination. First, it was supposed to be for secondary education and then the ones that were left were sent to Proeja. I learned a lot from the pro-integrative project and the researches and presentations helped a lot as well (Student A, 2012).

Unfortunately, inside the education system, the older teachers (a few, fortunately) have not yet understood the new education policy for the country and end up resorting to educational policies from the past decades, where the bank education (referred by Paulo Freire) is still valued. They complicate the content and seem to take pleasure in keeping crowded rooms of students that need remedial classes as if it were the ideal thing, perhaps in an attempt to undermine the new face of education using these dependencies as a device to keep the IFES 'elite' as it has been in decades (Student B, 2012).

From Proeja teachers' point of view, those who work for IFES, there is a division of interests between those working specifically in the technical area and those of the human sciences. Generally, the former rejects the program and consequently causes the drop out and/or failure of the student. As for the teachers of the humanities, after a few years of work, they started to understand and improve their practice. The following quote summarizes the general thinking of teachers, revealing dubiousness.

Proeja came to include the poor people of school and work settings. This goal seems that it will be achieved, albeit slowly. Many students spend more time adapting themselves to the new changing times and technologies presented at school today (Teacher - Human Sciences, 2012). (Oliveira, Scopel, \& Ferreira, 2013).

The example of Proeja shows the tension between a democratization project installed in a context dominated by an instrumental logic, in which the educational institution is facing strict compliance with the market. In fact, when we seek democratization of education policies with a view to insert a population that was segregated from their social rights, the management of the educational institution is pressed by the managerial reality that seeks to achieve the efficiency and effectiveness of educational goals.

The same can be seen with the implementation of the Integrated School Program, whose origin occurred within the movement of concerned educators to recover the losses incurred by the execution of practices that came to close the doors of schools for student workers. This program was under the inspiration of the Gramscian perspective of unitary school. Testimonials about this process (its contradictions) are recorded in Frigotto, Ciavatta and Ramos's (2005) text, the main protagonists of this policy. In this particular text, the authors highlight the consultants hired by MEC to give support to the Secretaries of Education of the regional states in more complex issues such as, for example, the construction of the pedagogical master plans of the schools: teacher training and school curricula.

Only in 2012 a new curricular structure was established by a new legislation that would set national curriculum guidelines for secondary education, after many debates sponsored by MEC and the National Education Council. These guidelines were discussed by segments of the scientific organizations and other movements that militated for secondary education in Brazil. Therefore, they represent an achievement of a curricular proposal that 
recognizes the relationship between work, science, technology and culture as integrating axes of knowledge from the perspective of work as an educational principle. However, this conceptual breakthrough is faced with political and economic limits found in the scope of the systems.

In addition to the recognized political and economic limits placed on education in a capitalist social reality that is underdeveloped, there is a pedagogical limit set by the evaluation policy for secondary education students: the National Secondary Education Examination (Enem in Portuguese). Enem, which is not mandatory, was created in 1998 as a way to assess the graduating secondary education students. It has become the largest examination of Brazil and the second largest in the world, behind only the examination in China. This growth is because Enem was improved in Lula da Silva's government as it has been also used as a mechanism of selection for admission to Higher Education since 2009. According to the agency responsible for its formulation and implementation (National Institute for Educational Studies and Research Anisio Teixeira-INEP), changes have been implemented in the exam that contribute to the democratization of the access to Federal Institutions of Higher Education (IFES), academic mobility and induce reorganization of the secondary education curriculum.

Enem follows Pisa when constructing items to measure the application of knowledge in practical life situations. Both use Item Response Theory (IRT) that allows comparisons between tests. The basic principle is that each individual has a latent and unobservable skill whose value determines the probability of success of an item that measures this ability and can be expressed in a single scale. Thus, Enem empties the meaning of the cognitive dimension, reducing it to a function of exchange value in the social market, "the positivity of knowledge is affirmed if it is expressed in know-how that may be exchanged for social benefits' (Lopes \& López, 2010, p. 103).

At first glance there is a paradox in education policies for secondary education in the country with the formulation of curriculum guidelines that seek to achieve the integration of knowledge through labour as an educational principle, and research as a pedagogical practice. At the same time, they invest large financial resources to carry out Enem, which is an exam that is accentuated when one observes the signing between MEC and Federal States (directly responsible for the provision of such education) of a National Pact for secondary education, that has massive investments in the continuing education of teachers for the implementation of national curriculum guidelines. Teachers, on the other hand, participate in training, but are routinely charged to prepare their students for Enem.

Thus, we can observe a combination of very diverse action records, which means that the actors who design and/or execute education policies are condemned to pursue contradictory goals. According to Muller (2011), there are at least two impasses to understand public action: the first is to consider that we are only in the presence of a public policy from the moment in which the actions and studied decisions form a coherent whole, something that never occurs. The second theoretical and methodological impass is to deny any rationality of public action due to the multiple inconsistencies that it manifests. As a possible resolution to this, Muller (2011) emphasizes that the work analysis must strive to bring to light the logics of action in the elaboration and implementation process of policies. In relation to logics of public action observed in policies for Secondary Education in Brazil, we identified the coexistence of civic logic organized around the right to education with the market logic that underlies the social ties in freedom and competition (Boltanski \& Chiapello, 2009). Tensions arising from these society projects in the context of globalization causes to prevail the management of measurable outcomes for performance, submitting other initiatives of democratic and popular character to the background.

\section{Final Considerations}

In the Brazilian democratization process, celebrated by the enactment of the Federal Constitution of 1988, the capitalist world in crisis puts in societies the imperative of modernization understood as the rational application of efficiency and effectiveness in the management of the public and private. Modernity, which in the 19th Century was national, moves to the deterritorialization in the globalization of the late 20th Century when the Nation-State lost its monopoly on setting the direction of social life (Ianni, 2001). The combination of modernization and social democratization, conceived as the logic of globalization in late capitalism, points to a more critical and severe relation of the limits and risks of the modern rationalist project.

The persistence of deep social inequalities has an effect on secondary education capacity to expand and destabilize the family heritage. Moreover, inequalities tend to increase when the differentiation of the types of educational institutions, curriculum prototypes and so many other forms of social reproduction analyzed by the Sociology of Education, continue to be the trademarks of the education pathways of most young people enrolled in secondary education. Ethics of equal opportunities, pursued in a discursive form in the liberal world, proved its bankruptcy in developed countries (Crahay, 2000; Peugny, 2014). 
In the context of expansion of the right to basic education in Brazil, education policies for secondary education are implemented to ensure the access and the retention of students in different types of schools. The myriad of projects and programs that invade the educational systems and schools may be the picture of public action in the education area, divided between Republicans and private interests, in the context of a State that loses its national and sovereign character, concerned with tax balance in a world of global disorder. The social class situations in the country are extensive and heterogeneous, guarded by deep inequalities, in which the work cannot often establish itself as a product for a part of the population. The reality of the secondary education offer is closely related to the condition of employment in the capitalist society.

In this complex framework, policies for secondary education seek its democratization in order to meet the principle of equal opportunities and also adjust youngsters to the work division. However, empirical evidences show very few effective results in relation to overcoming problems. Maybe because these problems are difficult to solve within the milestones of capitalism, or even the actual existence of a broader conception of the problems indicate that 'the process of education cannot only be thought of within the universe of reason and justice' (Derouet, 2010, p. 1021). Perhaps the heterogeneity in the offer of schools is the way to meet the diversity and differences currently experienced in secondary education.

Nonetheless, one cannot conceive education as a way of providing adaptations to the social environment, but enable a better understanding of the material and social reality in order to master it and transform it. A school that pursues a pedagogy based on these principles is not only an active school, but it is also vivid and creative. It is a living school as it builds a deep and organic connection between itself and the specific social dynamics that it identifies. It is creative because self-discipline, moral and intellectual autonomy are sought as students identify the organic relationship with the social dynamism that they experience, in the sense of not keeping it as a dominated class, but transforming it.

\section{References}

Boltanski, L., \& Chiapello, E. (2009). O novo espirito do capitalismo. São Paulo: Martins Fontes.

Capes/Proeja/Setec. (2012). Educação profissional no ensino médio: desafios da formação continuada de educadores na educação de jovens e adultos no âmbito do PROEJA no Espirito Santo. Vitória: UFES.

Carta Capital. (2011). De zero a dez. Revista Carta Capital, 675, 28.

Crahay, M. (2000). Poderá a escola ser justa e eficaz? Da igualdade das oportunidades à igualdade dos conhecimentos. Lisboa: Instituto Piaget.

Cury, C. R. J. (2011). A educação básica no Brasil. Educação \& Sociedade, 23(80), 168-200.

Delvaux, B. (2007). L'action publique, ou analyser la complexité. Revue de la littérature. Retrieved from http://knowandpol.eu/IMG/pdf/lr.tr.delvaux1.fr.pdf

Derouet, J. L. (2003). Entre a recuperação dos saberes oriundos da crítica e a construção dos padrões do 'management' liberal: pesquisa, administração e política na França de 1975 a 2005. In E. B. Ferreira, \& D. A. Oliveira (Eds.), Crise da escola e políticas educativas (pp. 25-41). Belo Horizonte: Autêntica.

Derouet, J. L. (2010). Crise do projeto de democratização da educação e da formação ou crise de um modelo de democratização? Algumas reflexões a partir do caso francês (1980-2010). Educação \& Sociedade, 31(112), 643-648. http://dx.doi.org/10.1590/S0101-73302010000300018

Esteve, J. M. (2006). Identidad y desafios de la condición docente. In E. Tenti Fanfani (Ed.), El oficio de docente: vocación, trabajo y profesión em el siglo XXI (pp. 67-80). Buenos Aires: Siglo veintiuno.

Faoro, R. (1958). Os donos do poder: formação do patronato politico brasileiro. São Paulo: Globo.

Ferreira, E. B.; Pochmann, M. (2011). Educação e juventude na sociedade pós-industrial. In D. A. Oliveira, \& A. Duarte (Eds.), Políticas públicas e educação: regulação e conhecimento (pp. 239-260). Belo Horizonte: Fino Traço.

Freire, P. (2001). Pedagogy of Freedom: Ethics, Democracy, and Civic Courage. Lanham: Rowman \& Lithefield Publishers Inc.

French, J. D. (2004). Drowning in Laws: Labor Law and Brazilian Political Culture. North Caroline: The University of North Carolina Press.

Frigotto, G., Ciavatta, M., \& Ramos, M. (2005). A politica de educação profissional no governo Lula: um percurso histórico controvertido. Educação \& Sociedade, 26(92), 1087-1113. http://dx.doi.org/10.1590/S0101-73302005000300017 
Furtado, C. (1976). Economic Development of Latin America: Historical Background and problems. New York. Cambridge University Press.

Gohn, M. G. (2011). Teorias dos movimentos sociais: paradigmas clássicos e contemporâneos. São Paulo: Loyola.

Herme, G., \& Trindade, H. (1988). The Paradoxes of Democracy. Delhi, India: Gian Publishing House.

Hobsbawm, E. (2005). Mundos do trabalho: novos estudos sobre a história operária. São Paulo: Paz e Terra.

Ianni, O. (2001). A sociedade global. São Paulo: Paz e Terra.

IBGE. (2013). Pesquisa nacional por amostra de domicílio. Retrieved from http:/www.ibge.gov.br/home/estatistica/populacao/trabalhoerendimento/pnad2014/default.shtm

INEP. (2013). Censo da educação superior. Brasil. Retrieved from http://www.inep.gov.br

IPEA. (2009). Políticas sociais: acompanhamento e análise. Retrieved from http://portal.inep.gov.br/basica-censo

Kuenzer, A. (2007). As relações entre trabalho e educação no regime de acumulação flexível: apontamentos para discutir categorias e politicas. Caxambu: ANPED.

Kuenzer, A. (2010). O ensino médio no plano nacional de educação 2011-2020: superando a década perdida? Educação \& Sociedade, 31(112), 851-873. http://dx.doi.org/10.1590/S0101-73302010000300011

Lima, L. C. (2003). A escola como organização educativa. São Paulo: Cortez.

Lopes, A. C., \& López, S. B. (2010). A performatividade nas políticas de currículo: O caso do ENEM. Educação em revista, 26(1), 89-110. http://dx.doi.org/10.1590/S0102-46982010000100005

MULLER, P. (2011). Les politiques publiques. Paris: Presses Universitaires de France.

MULLER, P., \& SUREL, Y. (2002). A análise das políticas públicas. Pelotas: Educat.

OECD. (2012). Education at a Glance 2012: OECD indicators. OECD Publishing. http://dx.doi.org/10.1787/eag-2012-en

Oliveira, E. C., Scopel, E., \& Ferreira, M. J. (2013). A experiência do Proeja: A visão dos múltiplos sujeitos envolvidos no programa do IFES-Campus Vitória. Revista Brasileira de Educação de Jovens e Adultos, 1(2). Retrieved from http://www.revistas.uneb.br/index.php/educajovenseadultos/article/view/576/450

Peugny, C. (2014). O destino vem do berço? Desigualdades e reprodução social. Campinas: Papirus.

PNAD. (2013). Pesquisa Nacional por Amostra de Domicílios. Brasil: IBGE.

Pochmann, M. (2015). Desigualdade econômica no Brasil. São Paulo: Ideias e Letras.

Tello, C., \& Mainardes, J. (2014). A educação secundária na América Latina como um direito democrático e universal: uma análise de documentos do Banco Mundial e do Banco Interamericano de Desenvolvimento. Educação e filosofia, 28(1), 155-179.

Tosto Jr., M. (2005). The meaning of liberalism in Brazil. Maryland: Lexington Books.

\section{Notes}

Note 1. Kuenzer (2007) criticizes the Brazilian educational system and vocational training that started to, from the 1990s, include the workers to exclude them throughout the process, either by expulsion (truancy) or the precariousness of teaching programmes that lead to unqualified certification.

Note 2. First elected president in Brazil coming from a working class background. Lula da Silva is co-founder of the Workers Party and was defeated electorally 3 times, only winning the elections at the fourth attempt in 2002. His election represented a victory for the social movements and leftist trade unions in the country.

Note 3. Vestibular is an entrance exam to Higher Education. It is a qualifying exam that consists of different disciplines, applied by public and private universities to students who intend to join Higher Education.

Note 4. For studies about Brazil see French (2004), Furtado (1976), Tosto Jr (2005), Herme \& Trindade (1988) and Freire (2001).

Note 5. National Household Sample Survey - PNAD, established in 1967, produces basic information for the study of socio-economic development of Brazil. The responsibility for producing and disseminating the National 
Household Survey is of the Brazilian Institute of Geography and Statistics - IBGE, the country main provider of data and information, which meets the needs of various segments of civil society, as well as organs of the federal levels of government, state and municipalities. IBGE is an entity of the federal government, under the Ministry of Planning, Budget and Management (www.ibge.gov.br). The site has an English version.

Note 6. To Faoro (1958), political power was exercised neither to serve the interests of agrarian classes and landowners nor those of the bourgeois classes, who were barely constituted as such. Political power was exercised in its own cause, by a social group whose characteristic was precisely to dominate the political and administrative machinery of the country, through which derived benefits of power, prestige and wealth. It was, in Weber's terms, a 'bureaucratic status', which was originated in the formation of the Portuguese State at the time of the discovery, if not before. This is reincarnated after what he calls the 'Brazilian political patronage'. The bureaucratic status had had its origin in what Weber called the 'paternalism', a form of typical traditional political domination of centralized systems that in the absence of a political decentralization of balance, evolve into modern forms of bureaucratic-authoritarian paternalism, as opposed to forms of rational-legal domination that prevailed in the capitalist countries of Western Europe.

Note 7. The name 'brown' to IBGE is the person who pleaded mulatto, cabocla, cafuza, mameluke or mixed black with people of another color or race.

\section{Copyrights}

Copyright for this article is retained by the author(s), with first publication rights granted to the journal.

This is an open-access article distributed under the terms and conditions of the Creative Commons Attribution license (http://creativecommons.org/licenses/by/4.0/). 